\title{
Review \\ Vitamin D and Primary Ciliary Dyskinesia: A Topic to Be Further Explored
}

\author{
Consolato M. Sergi ${ }^{1,2,3,+}$ \\ 1 Pathology Laboratories, Children's Hospital of Eastern Ontario, University of Ottawa, \\ Ottawa, ON K1H 8L1, Canada; csergi@cheo.on.ca \\ 2 Department of Laboratory Medicine and Pathology, University of Alberta, Edmonton, AB T6G 2B7, Canada \\ 3 Wuhan University of Science and Technology, Wuhan 430074, China \\ + Current address: Pathology Laboratories, Children's Hospital of Eastern Ontario, 401 Smyth Rd, \\ Ottawa, ON K1H 8L1, Canada.
}

check for updates

Citation: Sergi, C.M. Vitamin D and Primary Ciliary Dyskinesia: A Topic to Be Further Explored. Appl. Sci. 2021, 11, 3818. https://doi.org/ 10.3390/app11093818

Academic Editors: Thomas S. Lisse and Francesca Silvagno

Received: 31 December 2020

Accepted: 19 April 2021

Published: 23 April 2021

Publisher's Note: MDPI stays neutral with regard to jurisdictional claims in published maps and institutional affiliations.

Copyright: (C) 2021 by the author. Licensee MDPI, Basel, Switzerland. This article is an open access article distributed under the terms and conditions of the Creative Commons Attribution (CC BY) license (https:/ / creativecommons.org/licenses/by/ $4.0 /)$.

\begin{abstract}
Primary ciliary dyskinesia (PCD) is a genetic disease characterized by abnormalities in ciliary structure/function. The diagnosis of PCD relies on a combination of clinical evaluation and ultrastructural (electron microscopic) analysis of the ciliary architecture. This diagnosis may be challenging due to clinical and genetic heterogeneity and artifacts during the ciliary ultrastructure preparation and assessment. Recently, vitamin D supplementation has been proposed for several groups probably suffering from D-hypovitaminosis. Some patients with inflammatory bowel disease may have significant malabsorption, and vitamin D supplementation in these patients is recommended. Two recent reports suggest that a low plasmatic level of this vitamin is present in the PCD population. The utility of vitamin D supplementation may be essential in this group of individuals, and further investigations are warranted. Still, in examining the literature papers, it seems relevant that the authors concentrate solely on lung function in both studies. Future studies should probably target the intestinal function in patients with PCD independently from the vitamin D supplementation to fully evaluate its role.
\end{abstract}

Keywords: vitamin D; supplementation; diet; primary ciliary dyskinesia; quality; health care

\section{Introduction}

Flagella and motile cilia show a conserved axonemal structure. They consist of a ring of nine microtubular doublets associated with a central pair of microtubules [1-4].

This architecture gives the classical $9+2$ microtubular arrangement often searched for in patients harboring a cilia's potential defect (Figure 1). In examining the ciliary ultrastructure, the diagram of a transverse section of a normal cilium depicts the internal ultrastructure and the ciliary axis used to identify cilia orientation concerning each other. A ciliary membrane typically surrounds the axoneme (central core). It has nine peripheral microtubule doublets and two single central microtubules (Figure 1). The ultrastructural analysis is, however, challenging and needs to be carried out in several sections. Often some parts may be in focus.

In contrast, other details of the ultrastructural investigation may show the limitations of this technique on getting focused images in all fields (Figure 2). 


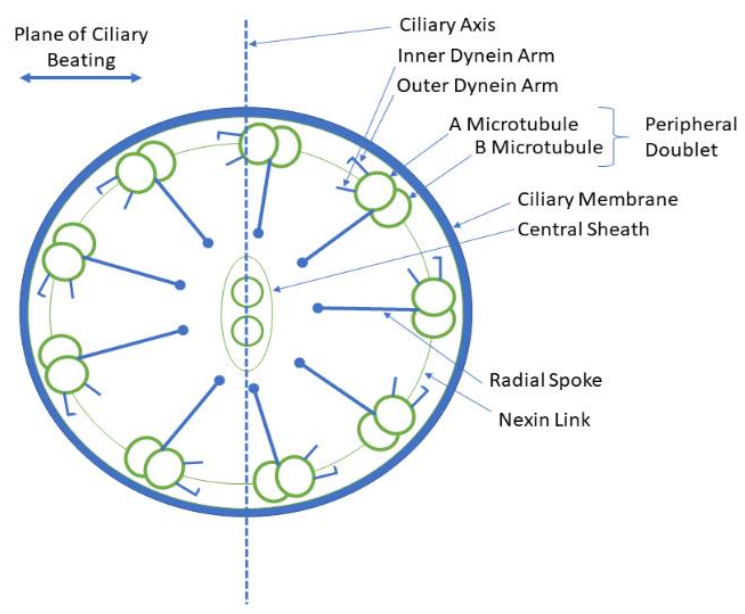

Figure 1. Ciliary Ultrastructu-re. A transverse section of a normal cilium is depicted in this diagram showing the internal ultrastructure and the ciliary axis used to identify cilia orientation with respect to each other. The central core or axoneme is surrounded by a ciliary membrane and has nine peripheral microtubule dou-blets associated with two single central microtubules.

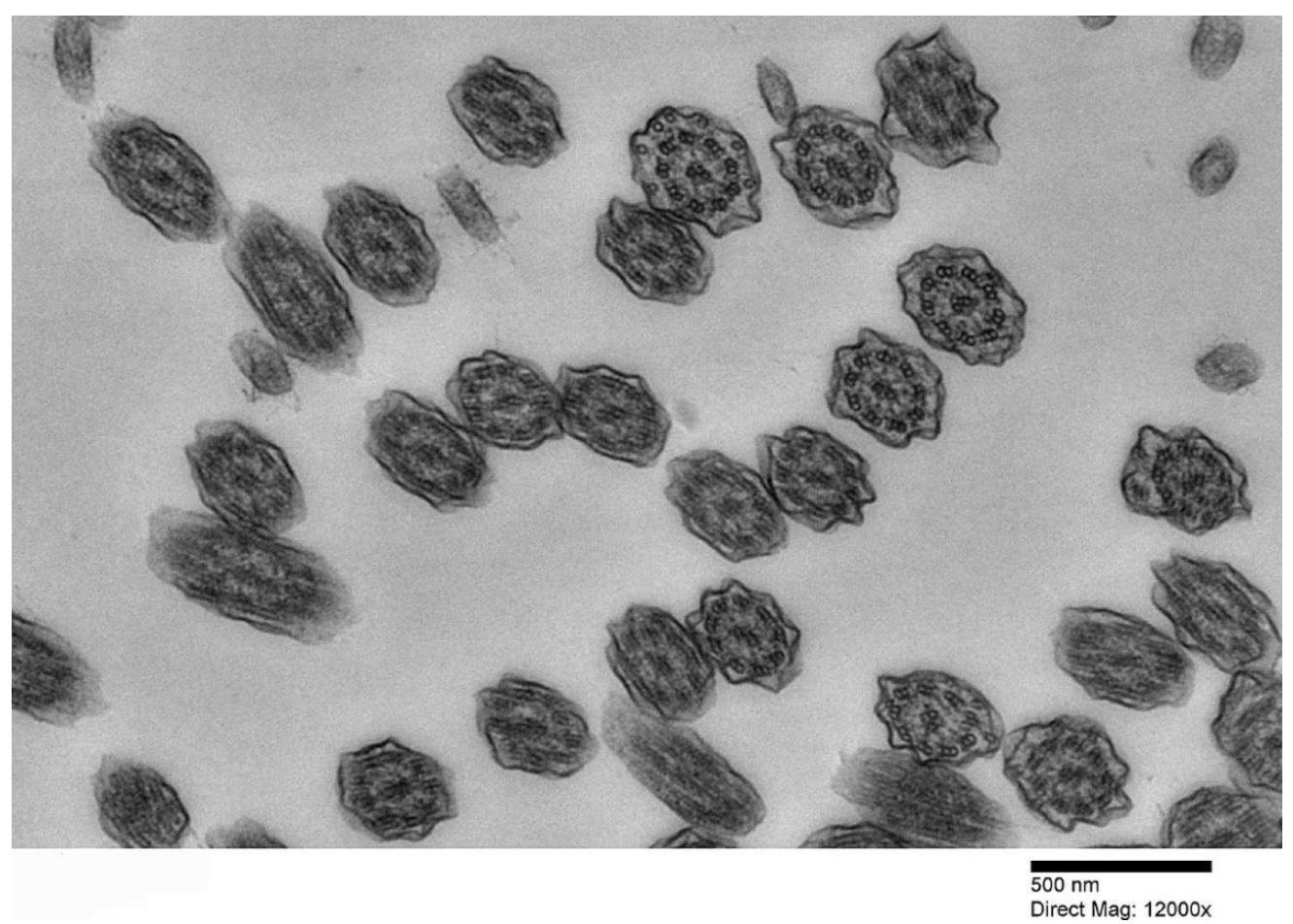

Figure 2. Cilia of a healthy individual showing a classic arrangement (transmission electron microscopy, see the bar for details regarding magnification). Some of these tangential sections were cut midway between the cell surface and the top of the waves. Ciliary cross-sections represent cilia in wave crests. Some cross-sections are not in focus because of the specific cut occurring at the time of the ciliary stroke. This is due to the technical difficulty in having all cross-sections with the same planar cut section.

There is a bridge-like structure interconnecting the central pair of microtubules $\mathrm{C} 1$ and C2. The bridge-like design and the central pair of microtubules constitute the main sheath or central pair complex (CPC). The composition of each outer doublet is critical, and there are type A and B microtubules connected by radial spokes (RS) to the CPC. The motility relies on the inner dynein arm's interaction (IDA) and outer dynein arm (ODA). They 
are carried by the A-type tubule and develop toward the B-microtubule of the adjacent doublet. IDA and ODA form part of a specific protein complex of $96 \mathrm{~nm}$ repeat unit. It includes four identical ODAs, six single-headed IDAs, one two-headed IDA, the three Rs, and a single nexin-dynein regulatory complex (N-DRC). The activity of the dynein arms is regulated and coordinated by the N-DRC. In the sperm flagellum, which has an ultrastructurally similar axonemal structure, accessory structures are also recognized. They include the mitochondrial sheath (MS), fibrous sheath (FS), and outer dense fibers (ODFs) [4]. This anatomy is specific to the sperm tail. They are needed for fertile sperm production and critical for the movement of the sperm in the female reproductive tract. Their central doublet must orientate neighboring cilia to beat in a coordinated way in a parallel fashion. Such ciliary beating coordination may be assessed by measuring the standard deviation of the angles formed between the central microtubules of neighboring cilia with the $\mathrm{x}$-axis $[5,6]$.

Motile cilia malfunction causes primary ciliary dyskinesia or PCD. It is a genetic disease, which affects nearly 1:10,000 people worldwide with slightly geographic variation [7]. The symptomatology begins in the newborn period. The spectrum includes a chronic nasal discharge associated with a wet cough. In childhood, it progresses to recurrent upper and lower respiratory infections. It may eventually evolve in pulmonary scarring with the formation of bronchiectasis. It is well known that a dysfunction of the airways' motile cilia is the basis of the symptoms. The airway motile cilia are specifically accountable for mucus clearance in the airways. In addition, motile cilia are crucial for the life of an organism. They are present in the brain, fallopian tube, eustachian tube, and middle ear. They function in fluid movement and play a crucial role in the embryonic node during development. Situs inversus, opposite of the situs solitus with a typical arrangement, is a congenital condition in which the major visceral organs are mirrored or reversed from their standard locations [8-10]. In approximately half of the patients harboring PCD, there are defects in the nodal cilia, which cause situs inversus $[8,11,12]$. PCD had some very well know eponyms and synonyms, including "Kartagener Syndrome" (bronchiectasis, chronic sinusitis, and situs inversus totalis) and "Immotile Cilia Syndrome" (after detection of immotile respiratory cilia and immotile sperm in subjects with Kartagener Syndrome) [13]. The different mutations cause different ciliary phenotypes, which also impact the clinical features of the disease. For example, a mutation that affects some components of the ODAs and IDAs may result in immotile cilia mutation that affects the radial spoke proteins resulting in cilia with circular motions. On the other side, mutations that affect CCDC39 and CCDC40 genes (Coiled-Coil Domain Containing proteins 39 and 40) induce a more severe clinical phenotype. The Coiled-Coil Domain-Containing Protein 114 gene (CCDC114) is associated with the biogenesis of cilia. It is crucial for the attachment of the outer dynein arms (ODAs) to the axoneme of cilia. Recently, mutations in the CCDC114 gene have been identified in a subtype of PCD named ciliary dyskinesia 20 (CILD20) [14-18]. In 78 patients with $\mathrm{PCD}$, Noone et al. investigated 76 patients using ciliary ultrastructural analysis [19]. The multiple PCD phenotypes included four major categories of structural ciliary defects. They are (1) outer dynein arm (ODA) alone, (2) inner dynein arm (IDA) alone, (3) defects in both outer and inner dynein arms, and (4) central apparatus defects. This last category is typically subdivided into defects of the central pair, radial spokes, or nexin links. They found defects in ODA alone, IDA alone, ODA and IDA combined, and central apparatus in $43 \%, 29 \%, 24 \%$, and $4 \%$, respectively [19]. Although heavily debated due to reproducibility issues in a clinical setting, the central doublet orientation deviations of over 20 degrees from each other may indicate the cilia's failure to move in a coordinated wave-like fashion $[5,6,20-23]$.

Although the ultrastructural analysis of cilia is quite well established worldwide, this assay has limited detection sensitivity. Not all PCD mutations cause cilia defects visualized by electron microscopy. The method is subject to artifacts due to numerous technical biases $[9,24]$. The functional analysis represents another critical approach toward our current understanding of ciliary motility. Still, this investigation remains technically 
challenging, and the relationship between ciliary motion and mucus transport has not been well characterized. The lifelong burden of PCD to pediatric patients changes probably slightly when they become adults. The focus moves on bronchiectasis, and the otologic disturbances become quite attenuated. However, the burden can be focused on fertility issues, mainly when the couple is attempting to have a child. Despite the extensive and increasing understanding of the spectrum of cilia structural defects in PCD, only a few reports concentrate on vitamin D's role in PCD. The scope of this narrative review is attempting to fill this gap in the medical literature.

\section{PCD under the Lens}

PCD is characterized by genetic heterogeneity with variable clinical impact. Genetic studies have discovered 40 PCD-associated genes. Mutations in known PCD genes are responsible for nearly 70\% of all PCD cases [13]. Predictably, more PCD genes will be found in this decade. There is an increasing awareness of this condition, and genetic sequencing has reached optimal levels. In tertiary centers, more patients with clinical phenotypes suggestive of PCD are often evaluated. The classic "hallmark" of PCD relies on the ultrastructural axonemal defects, including an absence of inner and outer dynein arms, absence of the outer dynein arm only, lack of inner dynein arms associated with microtubular disorganization, and/or central pair organization defects (Figure 3) [25].

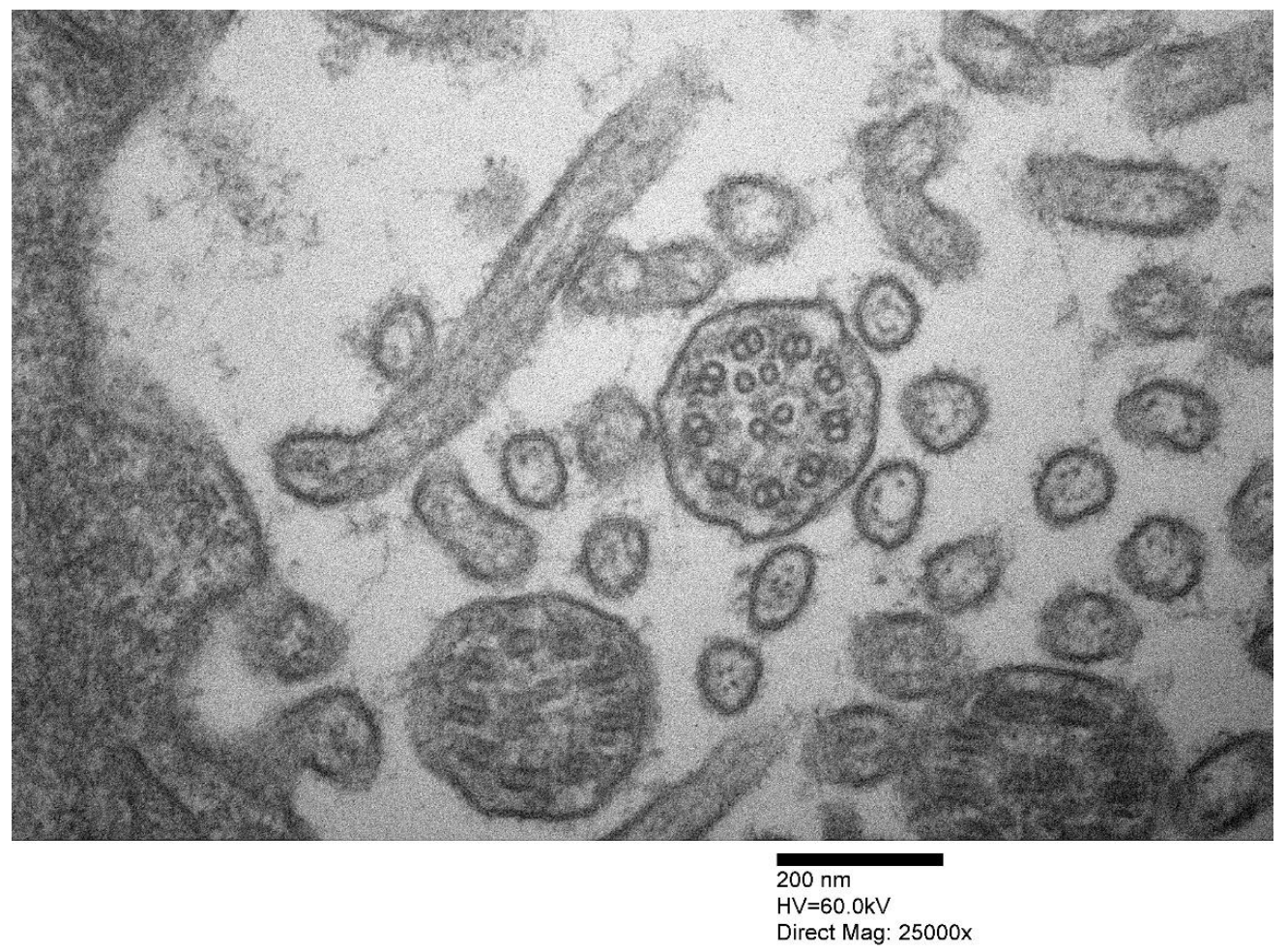

Figure 3. Cilia of a patient with primary ciliary dyskinesia showing microtubular disorganization (transmission electron microscopy, see the bar for details regarding magnification).

It has been projected that approximately one-third of genetically proven PCD cases have standard or normal-appearing ciliary axonemal structure. In addition to artifacts and suboptimal expertise in some morphologists, this data emphasizes electron microscopy limitations to detect subtle changes in structure. Although the transmission electron microscopy (TEM) is still key for the diagnosis with the analysis of the respiratory epithelium by nasal brushing for identification of ciliary structural defects, there are also more tests for making a diagnosis of PCD under all circumstances. The clinical history (neonatal respiratory distress, body laterality defects) should be accompanied by a series of tests that can be used to confirm the diagnosis. Nasal nitric oxide gas is decreased in most patients 
with PCD. In addition, defects of the ciliary beat pattern and frequency can be identified by high-speed video microscopy analysis (HSVMA) [26]. HSVMA harbors tremendous rates of sensitivity and specificity for PCD. In particular, specific beat patterns have been linked to specific ultrastructural defects. The analysis should also include immunofluorescence to look at cilia protein defects, which can be associated to more specialized TEM. The identification of numerous genes coding for proteins, which have a prominent role in motile cilia structure, formation, and function, has placed this technique in the forefront in most tertiary centers dealing with PCD patients. Moreover, gene panels have currently been proposed in numerous centers independently from the genetic heterogeneity [4].

\section{Vitamin D}

The "English Disease" or rickets, scurvy, and beriberi are known to have accompanied human civilization for centuries in both old and new continents [27-29]. Rickets is no longer considered the disease relegated to history or limited to low-income countries. Although not uniformly accepted, some reviews and clinical studies have pinpointed the low vitamin D level in patients affected by COVID-19 [30-33]. This aspect has brought significant attention to this component's crucial role in our diet [28]. Up to the end of the 1990s there was not much interest in nutritional rickets. After the turn of the century, there was a resurgence of interest in rickets and vitamin D status. The number of original reports and systematic reviews of patients and diseases associated with vitamin D deficiency was vastly increasing. Numerous clinical laboratories are being asked to measure the circulating 25-hydroxy $(\mathrm{OH})$-vitamin $\mathrm{D}(25[\mathrm{OH}] \mathrm{D})$ levels in both pediatric and adult patients [34-38]. In addition, vitamin $\mathrm{D}$ may have a crucial role in bone osteoporosis, which may be essential in migrants and individuals with HIV infection [39-43]. Child neglect cases discovered in forensic practice and unpublished cases debated only in courts may represent the tip of an iceberg $[29,44]$. Of note, extensive population surveys, such as the Nutrition Examination Survey and National Health, suggest that important sectors of infant and childhood and pregnant women populations are or will be affected by vitamin D inadequacy (at some point) in their life [45-50]. The change of the habits with indoor living, less sunlight exposure, dietary choices, and increasing rates of dietary allergy are likely playing a significant role in the increase of this rate in some segments of the worldwide population, according to the most recent evaluation of public health indicators [48,51-59].

Vitamin D is a fat-soluble vitamin. It has a unique metabolic pathway. It is predominantly made in the skin during sunlight exposure, unlike vitamins $\mathrm{A}, \mathrm{E}$, and $\mathrm{K}$. These three vitamins are rigorously absorbed from the diet. Indoor living is a significant drawback to our civilization. Conventionally, vitamin D plays a leading role in calcium homeostasis. Vitamin D deficiency is an essential cause of rickets, osteomalacia, and osteoporosis in the human population [60-63]. The most recent immunologic evidence indicates that vitamin $\mathrm{D}$ is tightly linked to immunity, inflammation, and cancer pathways [64-66]. The immune system cellular components possess vitamin D receptors (VDRs). These receptors are capable of metabolizing the active form of vitamin $\mathrm{D}$ [calcitriol, 1,25-dihydroxy vitamin $\mathrm{D}$, $\left.1,25(\mathrm{OH})_{2} \mathrm{D}\right]$ [67-70]. The storage form of vitamin $\mathrm{D}$ is 25-hydroxyvitamin $\mathrm{D}$ or 25(OH)D. It can be converted by activated $\mathrm{T}$ and $\mathrm{B}$ cells to $1,25(\mathrm{OH})_{2} \mathrm{D}$ in human cells in vitro [71]. There is a local activity of $1,25(\mathrm{OH}) 2 \mathrm{D}$ on immune cells with autocrine or paracrine fashion. This aspect is crucial in the infection, as suggested in COVID-19 infection, the coronavirus 2019 infection caused by the Severe Acute Respiratory Syndrome type II (SARS-CoV-2), despite controversial data [30-33].

Moreover, peripheral blood mononuclear cells (PBMC) harbor VDR providing support for vitamin D's significant role in regulating the immune system and infectious diseases [72]. Other than activity on immune cells, vitamin D increases the absorption of calcium from the small intestine. This aspect visibly showed that vitamin $\mathrm{D}$ is an essential factor in the utilization of dietary calcium. Nicolaysen et al. and Haavaldsen et al. also observed that animals on a low calcium diet had much greater calcium absorption efficiency than animals fed an adequate amount of calcium [73-75]. As identified that calmodulin is localized 
in the hamster's ciliated cells, and the prominent role of calcium for cilia's bioenergetic activity, the connection with immunity is more robust [76-81].

Vitamin D is crucial in maintaining airway homeostasis and innate immunity [82-85]. Vitamin D is a potent fat-soluble vitamin essential for healthy bones and cell growth and immune function. Vitamin D is known for its role in the regulation of calcium homeostasis and bone metabolism. Still, multiple studies have shown that it also acts as an essential regulator of host defense and immunity, including respiratory host defense. Transforming growth factor-beta 1 (TGF- $\beta 1$ ) reduces the host defense of airway epithelial cells by altering the vitamin D-mediated expression of host defense peptides and proteins [82]. When primary CD4+ T cells from healthy donors were cultured in Th17-polarizing conditions, vitamin D reduced the expression of Th17 markers and their secretion of proinflammatory cytokines. It entailed mainly interleukin 17A (IL-17A) and interferon-gamma (IFN- $\gamma$ ). It induced an expansion of CD4+ T cell subset expressing the highest levels of CD25 (termed CD25 ${ }^{\text {hi }}$ ) cells. It also upregulated their expression of CTLA-4 and Foxp3 regulatory markers [86]. In addition, the active form of vitamin D3 during CD8+ T-cell differentiation prevented IL-4-induced conversion to Tc2 IL-13 producers [83,86,87]. It seems that this may be particularly relevant for asthmatic children. Several studies have identified that low serum levels of vitamin D are associated with increased exacerbations, decreased lung function, increased airway inflammation, and, ultimately, poor prognosis in asthmatic patients [85]. Several studies, principally in children, suggest that vitamin D insufficiency is associated with asthma severity and more inadequate control [83]. Finally, there are two studies in healthy children where vitamin D's preventive administration lowered the respiratory infection risk [88,89]. Influenza A occurred in $10.8 \%$ of a group of 167 schoolchildren receiving $1200 \mathrm{IU} / \mathrm{d}$ vitamin D3. This data was significantly lower than the placebo group, where over $18.6 \%$ of children were infected. In healthy kids, Xiao et al. [90] found that only in the Urashima's study [88], where the risk of viral infection was lowered, was the vitamin D supplementation $1200 \mathrm{IU} / \mathrm{d}$. However, vitamin D supplement plays a non-novel role in regulating lung microbiome and airway function. Still, it seems to positively affect patients suffering from inflammatory bowel disease by modulating the gut microbiome and increasing the abundance of beneficial bacterial strains [84]. The cause of the growth failure of patients with PCD may be multifactorial and is likely because of increased respiratory effort, possible effects of chronic inflammation, and suboptimal nutrition intake, although a duodenal biopsy is rarely part of the workup of PCD patients and to our knowledge, this has yet to be described. A comprehensive study between the University of Alberta, Edmonton, Alberta, Canada, the Department of Gastroenterology and Hepatology, Vrije Universiteit Medical Center, Amsterdam, and The Netherlands on potential abnormal duodenal histology in several categories with malabsorption was performed [91].

Vitamin D is a vital supplement to the human diet. Although most people are satisfactorily protected against vitamin D deficiency, others show a level of susceptibility to develop such deficiency, which may target several critical functions of the organism. The National Institutes for Health (NIH) recommends supplementation of this vitamin D for some categories. They include exclusively and partially breastfed infants, people living in colder climates and less sunlight exposure, housebound people, or individuals who work night shifts, harboring a body mass index (BMI) of 30 or over, who have undergone gastric bypass surgery, suffering from inflammatory bowel disease, or cover their skin for religious reasons. The infants should receive 400 international units (IU) (10 micrograms [mcg]) of vitamin D per day until weaning. The dosage for other age groups varies. Up to the 70th year of age, the dosage of vitamin D supplementation is $600 \mathrm{IU}(15 \mathrm{mcg})$.

In contrast, individuals older than 70 years should receive $800 \mathrm{IU}(20 \mathrm{mcg})$ of vitamin D. On the other hand, skin exposure for 5-30 min, with the face, arms, legs, or back exposed, may be enough for most individuals at least twice per week. However, underlying conditions may still require supplementation to be added. 


\section{Vitamin D Role in PCD}

There is a positive association between lung function and body mass index in PCD [92,93], but the nutritional status of children affected with PCD may be relatively low. Marino et al. found that the healthy phenotype of a cohort of children with PCD may be quite altered [94]. Although weak, there is an association between lung function and nutritional status and the bioelectrical impedance spectroscopy (BIS) phase-angle measures. BIS has been explicitly utilized to determine body composition in different settings. It has been shown to identify differences in nutritional state and clinical outcome. Marino et al. emphasized that the use of BIS phase-angle may allow for early identification of at-risk children and may, therefore, be of benefit for nutritional assessments in the appropriate clinical setting [94]. A low BIS phase angle is associated with more inferior dietary status, which may precede anthropometric changes and impact clinical outcomes. Marino et al. found that in children with PCD, there were some associations between BIS phase angle, nutritional status, and clinical outcomes. They advocate for the routine use of BIS phase angle to add sensitivity and specificity in identifying children with nutritional risk earlier than using anthropometry alone. Marino et al.'s study [94] is paramount for identifying PCD patients at nutritional risk and looking for biomarkers of chronic inflammation in PCD. Their study involved 43 children, of which $51 \%$ were male. The average age at diagnosis was $2.7 \pm 3.8$ years, and at the time of the survey was $7.0 \pm 3.6$ years. Although none of the children studied had a low energy intake, $63 \%$ had excessive intake and $6 \%$ of children consumed inadequate amounts of protein, and $72 \%$ had a consumption of protein $200 \%$ of the reference nutrient intake (RNI) $[95,96]$. The authors found no associations between energy and protein intake concerning BMI, height for age, or BIS phase angle. Although there were no statistically significant variations between the groups, the FEV1 z score was higher in those with a protein intake of $200 \%$ of RNI than those with an adequate protein intake. Remarkably, vitamin D insufficiency $(<50 \mathrm{nmol} / \mathrm{L})$ was detected in $54 \%$ of the patients in the cohort where the plasma was available. Marino et al.'s study data are critical because children in their cohort had insufficient vitamin D levels, but all other micronutrient levels were within the normal range. The observation that lower nutritional status is associated with more impaired lung function in PCD patients, although weak, is similar to that seen in patients with cystic fibrosis (CF), with a relationship described between FEV1 and BMI. Although CF's main nutritional issues are probably due to intestinal malabsorption secondary to pancreatic insufficiency, PCD patients' data may be puzzling. This aspect may suggest that chronic suppurative lung disease, independently from pancreatic involvement, may negatively impact nutritional status [97]. This data may indicate that an abnormal ciliary function is associated with malabsorption but need to be explored further in future extensive studies. Marino et al.'s research findings are utmost. Still, limitations need to be considered, including dietary intake methods and a three-day semiquantitative food diary different from the seven-day diary. Apart from the suggested benefit of a multicenter design, the potentiality to evaluate a duodenal biopsy may be expected for complete identification of the normal intestinal anatomy [91].

Another study involved the measurement of vitamin D levels in 22 patients with PCD [98]. Mirra et al. [98] studied 15 males and seven females, 10.5 years (range, 2-34 years). These authors found that $72 \%$ of PCD patients were vitamin-D deficient-to-insufficient and $28 \%$ only were sufficient. In addition, $79 \%$ of PCD individuals had limitations in performing vigorous activities, and 53\% completed less than $3 \mathrm{~h}$ of physical activity per week. Mirra et al.'s study data are also vital because they found hypovitaminosis D in young Italian individuals. The subjects attended the Department of Translational Medical Sciences, Federico II University, Naples, Italy, the reference center for PCD in Campania, Southern Italy. Patients lived in Naples metropolitan area (latitude, $40^{\circ} 49^{\prime} \mathrm{N}$; elevation, $17 \mathrm{~m}$ ) and were evaluated from March through June 2012. These two aspects are fundamental because Naples is in Italy's Southern regions, and the observation was in the spring of the year. Thus, we would probably expect lower vitamin D levels in the northern areas of Italy or Europe and winter. 
Another aspect, which has not been raised by the authors in their cross-sectional study, concerns the affected individuals' diet. In Campania, cheese and milk products are the mainstays of their diet. Thus, if we consider Mirra et al.'s findings and associated with the Marino's data, we should strongly suggest evaluating these individuals' duodenal function. Vitamin D plays a crucial part in improving the innate immune response [83]. Interestingly, there is some evidence that vitamin $\mathrm{D}$ is also valuable for the current pandemic of COVID-19, a multisystemic infection caused by SARS-CoV-2 [99-101]. These two studies reveal an extra-immunologic role of vitamin $\mathrm{D}$, particularly the correct intestinal absorption. Vitamin D may play a considerable role in the growth and of individuals with PCD. Children in Western societies are, however, also at risk if living in high-risk groups. Dwyer et al. [102] studied records of preschool vegetarian children's dietary intake. They found that a macrobiotic vegetarian diet provides marginal amounts of vitamin $\mathrm{D}$, calcium, and phosphorus. Children on macrobiotic diets show physical and roentgenographic findings indicative of nutritional rickets more often than in the case of other vegetarian diets. Dagnelie et al. also studied vitamin D metabolism in Caucasian 10-20-month-old infants on a macrobiotic and omnivorous diet. These authors found that low availability of the calcium mineral in the macrobiotic diet was an independent factor in causing the high prevalence of rickets in these infants [103]. The macrobiotic diet precludes milk products and incorporates a high fiber intake. Both factors may have adverse effects on bone development in young children. Occult rickets cases have been reported and represent a drama for Asian immigrant children in the United Kingdom and worldwide [104-111].

\section{Conclusions}

In this paper, we revised the PCD and considered the increasing role of hypovitaminosis $\mathrm{D}$ with this genetic disease. A caveat of this review is that very few previous investigations target the role of vitamin D in PCD disease, so it is difficult to make conclusions based on this review. The results from Mirra et al. and Marino et al. are insufficient to suggest a role of vitamin D in PCD. Both studies found no significant differences in pulmonary functions between patients with adequate and inadequate vitamin D supplementation. However, PCD patients suffer from frequent airway infections that could be exacerbated by low vitamin D's influence on the lung and overall immunity. Vitamin D supplements may not be considered facultative. It seems that vitamin D supplements should be regular during the first twelve months of life but only one-third of children should continue to receive the supplement beyond one year of age. From one perspective, details of patients' diet affected with PCD should represent the focus of studies in the future.

Funding: This research has been funded by the generosity of the Children's Hospital of Eastern Ontario, Ottawa, Ontario, and the Stollery Children's Hospital Foundation and supporters of the Lois Hole Hospital for Women through the Women and Children's Health Research Institute (WCHRI, Grant ID \#: 2096), Hubei Province Natural Science Funding for Hubei University of Technology (100Talent Grant for Recruitment Program of Foreign Experts Total Funding: Digital PCR and NGS-based diagnosis for infection and oncology, 2017-2022), Österreichische Krebshilfe Tyrol (Krebsgesellschaft Tirol, Austrian Tyrolean Cancer Research Institute, 2007 and 2009_"DMBTI and cholangiocellular carcinomas" and "Hsp70 and HSPBP1 in carcinomas of the pancreas"), Austrian Research Fund (Fonds zur Förderung der wissenschaftlichen Forschung, FWF, Grant ID L313-B13), Canadian Foundation for Women's Health ("Early Fetal Heart-RES0000928"), Cancer Research Society (von Willebrand factor gene expression in cancer cells), Canadian Institutes of Health Research (Omega-3 Fatty Acids for Treatment of Intestinal Failure Associated Liver Disease: A Translational Research Study, 2011-2014, CIHR 232514), and the Saudi Cultural Bureau, Ottawa, Canada. The funders had no role in study design, data collection, and analysis, decision to publish, or preparation of the manuscript.

Institutional Review Board Statement: The study was conducted according to the guidelines of the Declaration of Helsinki, and approved by the Institutional Review Board of the University of Alberta under the major theme "Molecular Pathology and Genetics of the Abnormalities of the Intrahepatic Biliary System" (protocol code: Pro00007657, date of approval: 26 August 2009). 
Informed Consent Statement: Informed consent was obtained for nasal brushing for all subjects. Anonymous reproduction of the electron microscopy is permitted in manuscripts classified as reviews.

Data Availability Statement: The data that support the findings of this study are available from the corresponding author upon reasonable request.

Conflicts of Interest: The author declares no conflict of interest.

\section{References}

1. Bhatt, R.; Hogg, C. Primary ciliary dyskinesia: A major player in a bigger game. Breathe 2020, 16, 200047. [CrossRef]

2. Legendre, M.; Zaragosi, L.-E.; Mitchison, H.M. Motile cilia and airway disease. Semin. Cell Dev. Biol. 2021, 110, 19-33. [CrossRef] [PubMed]

3. Lee, L.; Ostrowski, L.E. Motile cilia genetics and cell biology: Big results from little mice. Cell. Mol. Life Sci. 2021, 78, 769-797. [CrossRef] [PubMed]

4. Sironen, A.; Shoemark, A.; Patel, M.; Loebinger, M.R.; Mitchison, H.M. Sperm defects in primary ciliary dyskinesia and related causes of male infertility. Cell. Mol. Life Sci. 2019, 77, 2029-2048. [CrossRef] [PubMed]

5. Tsang, K.W.; Tipoe, G.L.; Mak, J.C.; Sun, J.; Wong, M.; Leung, R.; Tan, K.C.; MedStat, C.K.M.; Ho, J.C.; Ho, P.L.; et al. Ciliary central microtubular orientation is of no clinical significance in bronchiectasis. Respir. Med. 2005, 99, 290-297. [CrossRef]

6. Tsang, K.W.; Zheng, L.; Tipoe, G. Ciliary assessment in bronchiectasis. Respirol. 2000, 5, 91-98. [CrossRef]

7. Marthin, J.K.; Petersen, N.; Skovgaard, L.T.; Nielsen, K.G. Lung function in patients with primary ciliary dyskinesia: A crosssectional and 3-decade longitudinal study. Am. J. Respir. Crit. Care Med. 2010, 181, 1262-1268. [CrossRef]

8. Wallmeier, J.; Nielsen, K.G.; Kuehni, C.E.; Lucas, J.S.; Leigh, M.W.; Zariwala, M.A.; Omran, H. Motile ciliopathies. Nat. Rev. Dis. Prim. 2020, 6, 77. [CrossRef]

9. Sergi, C.M. Pathology of Childhood and Adolescence; Springer Nature: Berlin, Germany, 2020.

10. Cave, D.; Ross, D.B.; Bahitham, W.; Chan, A.; Sergi, C.; Adatia, I. Mitochondrial DNA depletion syndrome-an unusual reason for interstage attrition after the modified stage 1 norwood operation. Congenit. Heart Dis. 2011, 8, E20-E23. [CrossRef]

11. Postema, M.C.; Carrion-Castillo, A.; Fisher, S.E.; Vingerhoets, G.; Francks, C. The genetics of situs inversus without primary ciliary dyskinesia. Sci. Rep. 2020, 10, 3677. [CrossRef]

12. Stern, B.M.; Sharma, G. Ciliary Dysfunction. In StatPearls [Internet]; StatPearls Publishing: Treasure Island, FL, USA, January 2021.

13. Leigh, M.W.; Horani, A.; Kinghorn, B.; O'Connor, M.G.; Zariwala, M.A.; Knowles, M.R. Primary ciliary dyskinesia (PCD): A genetic disorder of motile cilia. Transl. Sci. Rare Dis. 2019, 4, 51-75. [CrossRef]

14. Chen, X.; Deng, S.; Xia, H.; Yuan, L.; Xu, H.; Tang, S.; Deng, H. Identification of a CCDC114 variant in a Han-Chinese patient with situs inversus. Exp. Ther. Med. 2020, 20, 3336-3342. [CrossRef] [PubMed]

15. Guo, Z.; Chen, W.; Wang, L.; Qian, L. Clinical and genetic spectrum of children with primary ciliary dyskinesia in China. J. Pediatr. 2020, 225, 157-165.e5. [CrossRef] [PubMed]

16. Li, P.; He, Y.; Cai, G.; Xiao, F.; Yang, J.; Li, Q.; Chen, X. CCDC114 is mutated in patient with a complex phenotype combining primary ciliary dyskinesia, sensorineural deafness, and renal disease. J. Hum. Genet. 2019, 64, 39-48. [CrossRef]

17. Fedick, A.M.; Jalas, C.; Treff, N.R.; Knowles, M.R.; Zariwala, M.A. Carrier frequencies of eleven mutations in eight genes associated with primary ciliary dyskinesia in the Ashkenazi Jewish population. Mol. Genet. Genom. Med. 2014, 3, 137-142. [CrossRef]

18. Knowles, M.R.; Leigh, M.W.; Ostrowski, L.E.; Huang, L.; Carson, J.L.; Hazucha, M.J.; Yin, W.; Berg, J.S.; Davis, S.D.; Dell, S.D.; et al. Exome sequencing identifies mutations in CCDC114 as a cause of primary ciliary dyskinesia. Am. J. Hum. Genet. 2013, 92, 99-106. [CrossRef] [PubMed]

19. Noone, P.G.; Leigh, M.W.; Sannuti, A.; Minnix, S.L.; Carson, J.L.; Hazucha, M.; Zariwala, M.A.; Knowles, M.R. Primary ciliary dyskinesia: Diagnostic and phenotypic features. Am. J. Respir. Crit. Care Med. 2004, 169, 459-467. [CrossRef]

20. Rayner, C.F.; Rutman, A.; Dewar, A.; Cole, P.J.; Wilson, R. Ciliary disorientation in patients with chronic upper respiratory tract inflammation. Am. J. Respir. Crit. Care Med. 1995, 151, 800-804. [CrossRef] [PubMed]

21. Rayner, C.F.; Rutman, A.; Dewar, A.; Greenstone, M.A.; Cole, P.J.; Wilson, R. Ciliary disorientation alone as a cause of primary ciliary dyskinesia syndrome. Am. J. Respir. Crit. Care Med. 1996, 153, 1123-1129. [CrossRef]

22. Rutman, A.; Cullinan, P.; Woodhead, M.; Cole, P.J.; Wilson, R. Ciliary disorientation: A possible variant of primary ciliary dyskinesia. Thorax 1993, 48, 770-771. [CrossRef]

23. Rutland, J.; De Iongh, R.U. Random ciliary orientation. N. Engl. J. Med. 1990, 323, 1681-1684. [CrossRef]

24. Sergi, C.M. Transmission Electron Microscopy of Pediatric Small Round Blue Cell Tumors Microscopy Science: Last Approaches on Educational Programs and Applied Research; Formatex Research Center: Badajoz, Spain, 2018.

25. Knowles, M.R.; Daniels, L.A.; Davis, S.D.; Zariwala, M.A.; Leigh, M.W. Primary ciliary dyskinesia. recent advances in diagnostics, genetics, and characterization of clinical disease. Am. J. Respir. Crit. Care Med. 2013, 188, 913-922. [CrossRef]

26. Bricmont, N.; Benchimol, L.; Poirrier, A.-L.; Grignet, C.; Seaton, C.; Chilvers, M.A.; Seghaye, M.-C.; Louis, R.; Lefebvre, P.; Kempeneers, C. Nasal brushing sampling and processing using digital high speed ciliary videomicroscopy-Adaptation for the COVID-19 pandemic. J. Vis. Exp. 2020, 10, e61949. [CrossRef] [PubMed] 
27. DeLuca, H.F. History of the discovery of vitamin D and its active metabolites. BoneKEy Rep. 2014, 3, 479. [CrossRef] [PubMed]

28. Zhang, M.; Shen, F.; Petryk, A.; Tang, J.; Chen, X.; Sergi, C. "English Disease": Historical notes on rickets, the bone-lung link and child neglect issues. Nutrients 2016, 8, 722. [CrossRef] [PubMed]

29. Sergi, C.; Linderkamp, O. Pathological case of the month: Classic rickets in a setting of significant psychosocial deprivation. Arch Pediatr. Adolesc. Med. 2001, 155, 967-968. Available online: https:/ /www.ncbi.nlm.nih.gov/pubmed/11483129 (accessed on 31 December 2020). [CrossRef]

30. Pinzon, R.T.; Pradana, A.A.W. Vitamin D deficiency among patients with COVID-19: Case series and recent literature review. Trop. Med. Health 2020, 48, 102. [CrossRef] [PubMed]

31. Wise, J. Covid-19: Evidence is lacking to support vitamin D's role in treatment and prevention. BMJ 2020, 371, m4912. [CrossRef]

32. Mariani, J.; Giménez, V.M.M.; Bergam, I.; Tajer, C.; Antonietti, L.; Inserra, F.; Ferder, L.; Manucha, W. Association between vitamin D deficiency and COVID-19 incidence, complications, and mortality in 46 countries: An ecological study. Health Secur. 2020. [CrossRef]

33. Santaolalla, A.; Beckmann, K.; Kibaru, J.; Josephs, D.; Van Hemelrijck, M.; Irshad, S. Association between Vitamin D and novel SARS-CoV-2 respiratory dysfunction-A scoping review of current evidence and its implication for COVID-19 pandemic. Front. Physiol. 2020, 11, 564387. [CrossRef]

34. Morris, H.A.; Turner, A.G.; Anderson, P.H. Vitamin-D regulation of bone mineralization and remodelling during growth. Front Biosci. 2012, 4, 677-689. Available online: http:/ / www.ncbi.nlm.nih.gov/pubmed/22201904 (accessed on 31 December 2020). [CrossRef]

35. Saggese, G.; Vierucci, F.; Boot, A.M.; Czech-Kowalska, J.; Weber, G.; Camargo, C.A.; Mallet, E.; Fanos, M.; Shaw, N.J.; Holick, M.F. Vitamin D in childhood and adolescence: An expert position statement. Eur. J. Nucl. Med. Mol. Imaging 2015, 174, 565-576. [CrossRef]

36. Vojinovic, J.; Cimaz, R. Vitamin D-Update for the pediatric rheumatologists. Pediatr. Rheumatol. 2015, 13, 18. [CrossRef]

37. Kalra, S.; Aggarwal, S. Vitamin D deficiency: Diagnosis and patient centred management. J. Pak. Med. Assoc. 2015, 65, 569-573. Available online: http:/ / www.ncbi.nlm.nih.gov/pubmed/26028397 (accessed on 31 December 2020). [PubMed]

38. Kitanaka, S. Vitamin D dependency and its treatment. Clin. Calcium 2016, 26, 277-283.

39. Biver, E.; Calmy, A.; Aubry-Rozier, B.; Birkhäuser, M.; Bischoff-Ferrari, H.A.; Ferrari, S.; Frey, D.; Kressig, R.W.; Lamy, O.; Lippuner, K.; et al. Diagnosis, prevention, and treatment of bone fragility in people living with HIV: A position statement from the swiss association against osteoporosis. Osteoporos. Int. 2019, 30, 1125-1135. [CrossRef] [PubMed]

40. Ceballos, M.E.; Carvajal, C.; Jaramillo, J.; Dominguez, A.; González, G. Vitamin D and bone mineral density in HIV newly diagnosed therapy-naive patients without any secondary causes of osteoporosis. Calcif. Tissue Int. 2019, 104, 42-49. [CrossRef] [PubMed]

41. Messina, O.D.; Wilman, M.V.; Neira, L.F.V. Nutrition, osteoarthritis and cartilage metabolism. Aging Clin. Exp. Res. 2019, 31, 807-813. [CrossRef]

42. Atteritano, M.; Mirarchi, L.; Venanzi-Rullo, E.; Santoro, D.; Iaria, C.; Catalano, A.; Lasco, A.; Arcoraci, V.; Gullo, A.L.; Bitto, A.; et al. Vitamin D status and the relationship with bone fragility fractures in HIV-infected patients: A case control study. Int. J. Mol. Sci. 2018, 19, 119. [CrossRef]

43. Cascio, A.; Colomba, C.; Di Carlo, P.; Serra, N.; Re, G.L.; Gambino, A.; Casto, A.L.; Guglielmi, G.; Veronese, N.; Lagalla, R.; et al. Low bone mineral density in HIV-positive young Italians and migrants. PLoS ONE 2020, 15, e0237984. [CrossRef]

44. Kepron, C.; Pollanen, M.S. Rickets or abuse? A histologic comparison of rickets and child abuse-related fractures. Forensic Sci. Med. Pathol. 2015, 11, 78-87. [CrossRef]

45. Chesney, R.W.; Mehls, O.; Anast, C.S.; Brown, E.; Hammerman, M.R.; Portale, A.; Fallon, M.D.; Mahan, J.; Alfrey, A.C. Renal osteodystrophy in children: The role of vitamin D, phosphorus, and parathyroid hormone. Am. J. Kidney Dis. 1986, 7, $275-284$. [CrossRef]

46. Pettifor, J.M.; Prentice, A. The role of vitamin D in paediatric bone health. Best Pract. Res. Clin. Endocrinol. Metab. 2011, 25, 573-584. [CrossRef] [PubMed]

47. Prentice, A. Nutritional rickets around the world. J. Steroid Biochem. Mol. Biol. 2013, 136, 201-206. [CrossRef]

48. Prentice, A. Vitamin D deficiency: A global perspective. Nutr. Rev. 2008, 66 (Suppl. 2), S153-S164. [CrossRef]

49. Prentice, A.; Schoenmakers, I.; Laskey, M.A.; de Bono, S.; Ginty, F.; Goldberg, G.R. Nutrition and bone growth and development. Proc. Nutr. Soc. 2006, 65, 348-360. Available online: http://www.ncbi.nlm.nih.gov/pubmed/17181901 (accessed on 31 December 2020). [CrossRef] [PubMed]

50. Chesney, R.W. Vitamin D and the magic mountain: The anti-infectious role of the vitamin. J. Pediatr. 2010, 156, 698-703. [CrossRef] [PubMed]

51. Beck-Nielsen, S.S. Rickets in Denmark. Dan. Med. J. 2012, 59, B4384. Available online: http://www.ncbi.nlm.nih.gov/pubmed/ 22293055 (accessed on 31 December 2020). [PubMed]

52. Alles, M.S.; Eussen, S.R.; Van Der Beek, E.M. Nutritional challenges and opportunities during the weaning period and in young childhood. Ann. Nutr. Metab. 2014, 64, 284-293. [CrossRef] [PubMed]

53. Ameen, S.; Staub, L.; Ulrich, S.; Vock, P.; Ballmer, F.; Anderson, S.E. Harris lines of the tibia across centuries: A comparison of two populations, medieval and contemporary in Central Europe. Skelet. Radiol. 2004, 34, 279-284. [CrossRef] [PubMed] 
54. Assiri, A.; Saeed, A.; Sarkhy, A.A.; Mouzan, M.I.E.; Matary, W.E. Celiac disease presenting as rickets in Saudi children. Ann. Saudi Med. 2013, 33, 49-51. [CrossRef] [PubMed]

55. Holick, M.F. High Prevalence of vitamin D inadequacy and implications for health. Mayo Clin. Proc. 2006, 81, 353-373. [CrossRef]

56. Kaganov, B.; Caroli, M.; Mazur, A.; Singhal, A.; Vania, A. Suboptimal micronutrient intake among children in Europe. Nutrients 2015, 7, 3524-3535. [CrossRef] [PubMed]

57. Pettifor, J.M. Vitamin D\&/or calcium deficiency rickets in infants \& children: A global perspective. Indian J. Med. Res. 2008, 127, 245-249. Available online: http:/ / www.ncbi.nlm.nih.gov/pubmed/18497438 (accessed on 31 December 2020). [PubMed]

58. Vahlquist, B. Two-century perspective of some major nutritional deficiency diseases in childhood. Acta Paediatr. Scand. 1975, 64, 161-171. Available online: http:/ / www.ncbi.nlm.nih.gov/pubmed/805508 (accessed on 31 December 2020). [PubMed]

59. Wandel, M. Nutrition-related diseases and dietary change among third world immigrants in northern Europe. Nutr. Health 1993, 9, 117-133. [CrossRef]

60. Alpert, P.T.; Shaikh, U. The effects of vitamin D deficiency and insufficiency on the endocrine and paracrine systems. Biol. Res. Nurs. 2007, 9, 117-129. [CrossRef]

61. Cruz, J.A.A. Nutrition and osteoporosis: Facts and uncertainties about calcium and vitamin D recommendations. Forum Nutr. 2003, 56, 178-181. Available online: http:/ / www.ncbi.nlm.nih.gov/pubmed/15806851 (accessed on 31 December 2020).

62. Calvo, M.S.; Uribarri, J. Public health impact of dietary phosphorus excess on bone and cardiovascular health in the general population. Am. J. Clin. Nutr. 2013, 98, 6-15. [CrossRef]

63. Cashman, K.D. Vitamin D in childhood and adolescence. Postgrad. Med. J. 2007, 83, 230-235. [CrossRef]

64. Sundaram, M.E.; Coleman, L.A. Vitamin D and influenza. Adv. Nutr. 2012, 3, 517-525. [CrossRef] [PubMed]

65. DeLuca, H.F. Vitamin D: Historical Overview. Vitam. Horm. 2016, 100, 1-20. [CrossRef]

66. Ogunkolade, B.W.; Boucher, B.J.; Fairclough, P.D.; Hitman, G.A.; Dorudi, S.; Jenkins, P.J.; Bustin, S.A. Expression of 25hydroxyvitamin D-1- $\alpha$-hydroxylase mRNA in individuals with colorectal cancer. Lancet 2002, 359, 1831-1832. [CrossRef]

67. Bah, S.Y.; Dickinson, P.; Forster, T.; Kampmann, B.; Ghazal, P. Immune oxysterols: Role in mycobacterial infection and inflammation. J. Steroid Biochem. Mol. Biol. 2017, 169, 152-163. [CrossRef]

68. Zittermann, A.; Pilz, S.; Hoffmann, H.; März, W. Vitamin D and airway infections: A European perspective. Eur. J. Med. Res. 2016, 21, 14. [CrossRef]

69. Gleeson, M. Immunological aspects of sport nutrition. Immunol. Cell Biol. 2015, 94, 117-123. [CrossRef]

70. Neme, A.; Nurminen, V.; Seuter, S.; Carlberg, C. The vitamin D-dependent transcriptome of human monocytes. J. Steroid Biochem. Mol. Biol. 2016, 164, 180-187. [CrossRef]

71. Chen, S.; Sims, G.P.; Chen, X.X.; Gu, Y.Y.; Chen, S.; Lipsky, P.E. Modulatory effects of 1,25-dihydroxyvitamin D3 on human B cell differentiation. J. Immunol. 2007, 179, 1634-1647. [CrossRef]

72. Manolagas, S.C.; Provvedini, D.M.; Tsoukas, C.D. Interactions of 1,25-dihydroxyvitamin D3 and the immune system. Mol. Cell. Endocrinol. 1985, 43, 113-122. [CrossRef]

73. Haavaldsen, R.; Egnund, K.M.; Nicolaysen, R. Studies in calcium metabolism in rats. II. The interaction of vitamin D and the endogenous factor. Acta Physiol. Scand. 1956, 36, 108-113. [CrossRef] [PubMed]

74. Haavaldsen, R.; Nicolaysen, R. Studies in calcium metabolism in rats. I. A long term study in rats given an optimal diet with and without vitamin, D. Acta Physiol. Scand. 1956, 36, 102-107. [CrossRef]

75. Nicolaysen, R. The influence of vitamin D on the absorption of calcium from the intestine of rats: Experiments with isolated loops. Acta Physiol. Scand. 1951, 22, 260-266. [CrossRef]

76. Sasaki, K.; Shiba, K.; Nakamura, A.; Kawano, N.; Satouh, Y.; Yamaguchi, H.; Morikawa, M.; Shibata, D.; Yanase, R.; Jokura, K.; et al. Calaxin is required for cilia-driven determination of vertebrate laterality. Commun. Biol. 2019, 2, 226. [CrossRef] [PubMed]

77. Auguste, Y.; Delague, V.; Desvignes, J.-P.; Longepied, G.; Gnisci, A.; Besnier, P.; Levy, N.; Beroud, C.; Megarbane, A.; MetzlerGuillemain, C.; et al. Loss of calmodulin- and radial-spoke-associated complex protein CFAP251 leads to immotile spermatozoa lacking mitochondria and infertility in men. Am. J. Hum. Genet. 2018, 103, 413-420. [CrossRef] [PubMed]

78. Van Hemelrijck, M.; Shanmugalingam, T.; Bosco, C.; Wulaningsih, W.; Rohrmann, S. The association between circulating IGF1, IGFBP3, and calcium: Results from NHANES III. Endocr. Connect. 2015, 4, 187-195. [CrossRef] [PubMed]

79. Upadhyaya, A.; Baraban, M.; Wong, J.; Matsudaira, P.; Van Oudenaarden, A.; Mahadevan, L. Power-limited contraction dynamics of vorticella convallaria: An ultrafast biological spring. Biophys. J. 2008, 94, 265-272. [CrossRef]

80. Plattner, H.; Hentschel, J. Sub-second cellular dynamics: Time-resolved electron microscopy and functional correlation. Adv. Virus Res. 2006, 255, 133-176. [CrossRef]

81. Gordon, R.E.; Williams, K.B.; Puszkin, S. Immune localization of calmodulin in the ciliated cells of hamster tracheal epithelium. J. Cell Biol. 1982, 95, 57-63. [CrossRef]

82. Schrumpf, J.A.; Ninaber, D.K.; Van Der Does, A.M.; Hiemstra, P.S. TGF- $\beta 1$ impairs vitamin D-induced and constitutive airway epithelial host defense mechanisms. J. Innate Immun. 2019, 12, 74-89. [CrossRef]

83. Zdrenghea, M.T.; Makrinioti, H.; Bagacean, C.; Bush, A.; Johnston, S.L.; Stanciu, L.A. Vitamin D modulation of innate immune responses to respiratory viral infections. Rev. Med. Virol. 2017, 27, e1909. [CrossRef]

84. Sun, J. Dietary vitamin D, vitamin D receptor, and microbiome. Curr. Opin. Clin. Nutr. Metab. Care 2018, 21, 471-474. [CrossRef]

85. Hall, S.C.; Agrawal, D.K. Vitamin D and bronchial asthma: An overview of data from the past 5 years. Clin. Ther. 2017, 39, 917-929. [CrossRef] 
86. Fawaz, L.; Mrad, M.F.; Kazan, J.M.; Sayegh, S.; Akika, R.; Khoury, S.J. Comparative effect of 25(OH)D3 and 1,25(OH)2D3 on Th17 cell differentiation. Clin. Immunol. 2016, 166-167, 59-71. [CrossRef] [PubMed]

87. Schedel, M.; Jia, Y.; Michel, S.; Takeda, K.; Domenico, J.; Joetham, A.; Ning, F.; Strand, M.; Han, J.; Wang, M.; et al. 1,25D3 prevents CD8+Tc2 skewing and asthma development through VDR binding changes to the Cyp11a1 promoter. Nat. Commun. 2016, 7, 10213. [CrossRef] [PubMed]

88. Urashima, M.; Segawa, T.; Okazaki, M.; Kurihara, M.; Wada, Y.; Ida, H. Randomized trial of vitamin D supplementation to prevent seasonal influenza A in schoolchildren. Am. J. Clin. Nutr. 2010, 91, 1255-1260. [CrossRef] [PubMed]

89. Camargo, C.A.; Ganmaa, D.; Frazier, A.L.; Kirchberg, F.F.; Stuart, J.J.; Kleinman, K.; Sumberzul, N.; Rich-Edwards, J.W. Randomized trial of vitamin D Supplementation and risk of acute respiratory infection in mongolia. Pediatrics 2012, 130, e561-e567. [CrossRef] [PubMed]

90. Xiao, L.; Xing, C.; Yang, Z.; Xu, S.; Wang, M.; Du, H.; Liu, K.; Huang, Z. Vitamin D supplementation for the prevention of childhood acute respiratory infections: A systematic review of randomised controlled trials. Br. J. Nutr. 2015, 114, 1026-1034. [CrossRef]

91. Sergi, C.; Shen, F.; Bouma, G. Intraepithelial lymphocytes, scores, mimickers and challenges in diagnosing gluten-sensitive enteropathy (celiac disease). World J. Gastroenterol. 2017, 23, 573-589. [CrossRef] [PubMed]

92. Pifferi, M.; Bush, A.; Pioggia, G.; Caramella, D.; Tartarisco, G.; Di Cicco, M.; Zangani, M.; Chinellato, I.; Maggi, F.; Tezza, G.; et al. Evaluation of pulmonary disease using static lung volumes in primary ciliary dyskinesia. Thorax 2012, 67, 993-999. [CrossRef]

93. Valerio, G.; Giallauria, F.; Montella, S.; Vaino, N.; Vigorito, C.; Mirra, V.; Santamaria, F. Cardiopulmonary assessment in primary ciliary dyskinesia. Eur. J. Clin. Investig. 2011, 42, 617-622. [CrossRef]

94. Marino, L.; Harris, A.; Johnstone, C.; Friend, A.; Newell, C.; Miles, E.; Lucas, J.; Calder, P.; Walker, W. Characterising the nutritional status of children with primary ciliary dyskinesia. Clin. Nutr. 2019, 38, 2127-2135. [CrossRef] [PubMed]

95. Kyle, U.G.; Bosaeus, I.; De Lorenzo, A.D.; Deurenberg, P.; Elia, M.; Gómez, J.M.; Heitmann, B.L.; Kent-Smith, L.; Melchior, J.-C.; Pirlich, M.; et al. Bioelectrical impedance analysis-Part II: Utilization in clinical practice. Clin. Nutr. 2004, 23, 1430-1453. [CrossRef]

96. Kyle, U.G.; Bosaeus, I.; De Lorenzo, A.D.; Deurenberg, P.; Elia, M.; Gomez, J.M.; Heitmann, B.L.; Kent-Smith, L.; Melchior, J.C.; Pirlich, M.; et al. Bioelectrical impedance analysis? Part I: Review of principles and methods. Clin. Nutr. 2004, 23, 1226-1243. [CrossRef] [PubMed]

97. Cohen-Cymberknoh, M.; Simanovsky, N.; Hiller, N.; Hillel, A.G.; Shoseyov, D.; Kerem, E. Differences in disease expression between primary ciliary dyskinesia and cystic fibrosis with and without pancreatic insufficiency. Chest 2014, 145, 738-744. [CrossRef]

98. Mirra, V.; Caffarelli, C.; Maglione, M.; Valentino, R.; Perruolo, G.; Mazzarella, C.; Di Micco, L.L.; Montella, S.; Santamaria, F. Hypovitaminosis D: A novel finding in primary ciliary dyskinesia. Ital. J. Pediatr. 2015, 41, 14-16. [CrossRef]

99. Khan, A.; Sergi, C. SAMHD1 as the potential link between SARS-CoV-2 infection and neurological complications. Front. Neurol. 2020, 11. [CrossRef]

100. Burnett, M.L.; Sergi, C.M. Face masks are beneficial regardless of the level of infection in the fight against COVID-19. Disaster Med. Public Health Prep. 2020, 14, e47-e50. [CrossRef]

101. Sergi, C.M.; Chiu, B. Targeting NLRP3 inflammasome in an animal model for coronavirus disease 2019 (COVID-19) caused by the severe acute respiratory syndrome coronavirus 2 (SARS-CoV-2). J. Med. Virol. 2021, 93, 669-670. [CrossRef]

102. Dwyer, J.T.; Dietz, W.H.; Hass, G.; Suskind, R. Risk of nutritional rickets among vegetarian children. Arch. Pediatr. Adolesc. Med. 1979, 133, 134-140. [CrossRef] [PubMed]

103. Dagnelie, P.C.; Vergote, F.J.; Van Staveren, W.A.; Berg, H.V.D.; Dingjan, P.G.; Hautvast, J.G. High prevalence of rickets in infants on macrobiotic diets. Am. J. Clin. Nutr. 1990, 51, 202-208. [CrossRef] [PubMed]

104. Green, T.J.; Li, W.; Barr, S.I.; Jahani, M.; Chapman, G.E.; Green, T. Vitamin D supplementation is associated with higher serum 25OHD in Asian and white infants living in Vancouver, Canada. Matern. Child. Nutr. 2012, 11, 253-259. [CrossRef] [PubMed]

105. Pettifor, J.M. Nutritional rickets: Deficiency of vitamin D, calcium, or both? Am. J. Clin. Nutr. 2004, 80 (Suppl. 6), 1725S-1729S. [CrossRef] [PubMed]

106. Koch, H.-C.; Burmeister, W. Vitamin D-status bei afrikanischen und asiatischen diplomatenkindern und -jugendlichen in Deutschland. Klin. Pädiatrie 1993, 205, 416-420. [CrossRef] [PubMed]

107. Boyle, I.T. Bones for the future. Acta Paediatr. 1991, 80, 58-65. [CrossRef]

108. Heald, F.P.; Rosebrough, R.H.; Jacobson, M.S. Nutrition and the adolescent: An update. J. Adolesc. Health Care 1980, 1, $142-151$. [CrossRef]

109. Goel, K.; Logan, R.; Arneil, G.; Sweet, E.; Warren, J.; Shanks, R. Florid and subclinical rickets among immigrant children in glasgow. Lancet 1976, 307, 1141-1145. [CrossRef]

110. Ford, J.A.; Davidson, D.C.; McIntosh, W.B.; Fyfe, W.M.; Dunnigan, M.G. Neonatal rickets in Asian immigrant population. Br. Med. J. 1973, 3, 211-212. [CrossRef]

111. Holmes, A.M.; Enoch, B.A.; Taylor, J.L.; Jones, M.E. Occult rickets and osteomalacia amongst the Asian immigrant population. QJM Int. J. Med. 1973, 42, 125-149. [CrossRef] 